\title{
Infecção mista pelo Sugarcane mosaic virus e Maize rayado fino virus provoca danos na cultura do milho no estado de São Paulo
}

\author{
Marcos César Gonçalves ${ }^{1}$, Ivan de Godoy Maia ${ }^{2}$, Sílvia Regina Galleti ${ }^{1}$ \& Gisèle Maria Fantin ${ }^{1}$
}

${ }^{1}$ Instituto Biológico, CPDSV, Av. Conselheiro Rodrigues Alves 1252, 04014-002 São Paulo, SP, Brazil; ${ }^{2}$ Universidade Estadual Paulista, Campus de Botucatu, IB, Departamento de Genética, 18618-000, Botucatu, SP.

Autor para correspondência: Marcos C. Gonçalves <mcgon@biologico.sp.gov.br>

Data da chegada: 24/05/2006. Aceito para publicação em: 23/04/2007.

1369

\section{RESUMO}

Gonçalves, M.C., Maia, I.G., Galleti, S.R., \& Fantin, G.M. Infecção mista pelo Sugarcane mosaic virus e Maize rayado fino virus provoca danos na cultura do milho no estado de São Paulo. Summa Phytopathologica, v.33, n.4, p.348-352, 2007.

Os dois principais vírus que infectam o milho no Brasil são o Sugarcane mosaic virus (SCMV) e o Maize rayado fino virus (MRFV), cujos principais vetores são o afídeo Rhopalosiphum maidis e a cigarrinha Dalbulus maidis, respectivamente. O MRFV é freqüentemente encontrado em infecções mistas com fitoplasmas e espiroplasmas, causando as doenças denominadas enfezamentos do milho. Em uma lavoura de milho próxima a Santo Antonio da Posse, SP, cercada por campos de cana-de-açúcar, foi encontrada alta incidência de plantas apresentando mosaico, riscas, nanismo e espigas com falhas no enchimento de grãos. Análises serológicas com anti- soros específicos detectaram a presença do SCMV e MRFV nessas plantas. A infecção pelo SCMV também foi confirmada por RT-PCR com primers específicos e análise de seqüências. Em observações de preparações contrastadas negativamente em TEM, partículas flexuosas (ca.770 nm) e isométricas (ca.30 nm) foram detectadas. Em cortes ultrafinos, inclusões citoplasmáticas, típicas de Potyviridae, foram observadas; não foi encontrada a presença de espiroplasmas nem de fitoplasmas. Esses resultados mostram que a infecção conjunta por SCMV e MRFV pode ser responsável pelos danos encontrados nessa lavoura.

Palavras-chave adicionais: Potyvirus, Marafivirus, Rhopalosiphum maidis, Dalbulus maidis.

\section{ABSTRACT}

Gonçalves, M.C., Maia, I.G., Galleti, S.R. \& Fantin, G.M. Mixed infection by Sugarcane mosaic virus and Maize rayado fino virus causing breaking yields in maize in São Paulo state. Summa Phytopathologica, v.33, n.4, p.348-352, 2007.

The two main viruses infecting maize in Brazil are Sugarcane mosaic virus (SCMV) and Maize rayado fino virus (MRFV), whose main vectors are the aphid Rhopalosiphum maidis and the leafhopper Dalbulus maidis, respectively. MRFV is frequently found in mixed infections with phytoplasms and spiroplasms causing the so-called corn stunting diseases. In a maize commercial field close to Santo Antonio da Posse, São Paulo state, surrounded by sugarcane fields, it was found a high incidence of plants showing mosaic, striping, stunting and cobs with decreased number of grains. Serological analysis with specific antisera detected the presence of SCMV and MRFV in these plants. SCMV infection was also confirmed by RT-PCR with specific primers and sequence analysis. In TEM observations of negatively stained preparations, flexuous $(\mathrm{ca} .770 \mathrm{~nm})$ and isometric particles $($ ca.30 nm) were detected. In ultrathin sections, cytoplasmic inclusions, typical of Potyviridae, were observed; neither presence of spiroplasms nor phytoplasms could be noted. These results show that mixed infection by SCMV and MRFV might be responsible for the crop losses.

Additional Keywords: Potyvirus, Marafivirus, Rhopalosiphum maidis, Dalbulus maidis.

No Brasil, as principais viroses incidentes na cultura do milho (Zea mays) são o mosaico e a risca, causados pelo Sugarcane mosaic virus (SCMV) e o Maize rayado fino virus (MRFV), respectivamente. Mundialmente, o mosaico pode ser causado por cinco espécies distintas de Potyvirus que infectam o milho e constituem um subgrupo viral: SCMV, espécie que dá nome ao subgrupo; Maize dwarf mosaic virus (MDMV); Johnsongrass mosaic virus (JGMV); Sorghum mosaic virus (SrMV) $(6,7,14)$ e o Zea mosaic virus (ZeMV), espécie recentemente sugerida como um novo membro do subgrupo (16). No Brasil, apenas as espécies SCMV e MDMV são descritas infectando naturalmente o milho. Há também um único relato de detecção serológica do JGMV no país (3). Os vírus do subgrupo do SCMV e suas diversas estirpes pertencem ao gênero Potyvirus, família Potyviridae (15), são transmitidos por várias espécies de afídeos, com maior eficiência por Rhopalosiphum maidis e Schizaphis graminum $(13,15)$, cuja incidência é comum no Brasil (17). Os sintomas iniciais de infecção em milho consistem em pontos cloróticos com disposição linear no meio, ou mais comumente, na base das folhas, que evoluem para áreas alongadas, formando um mosaico típico, o qual pode aumentar de severidade ao decorrer da infecção. O crescimento das plantas pode ser acentuadamente reduzido, conforme a espécie e estirpe do vírus e a cultivar de milho, principalmente quando a infecção ocorre nos estágios iniciais de desenvolvimento. Ocasionalmente, em cultivares mais suscetíveis, pode ocorrer o encurtamento dos entrenós. Atualmente, a doença não ocasiona grandes danos à cultura devido ao uso de híbridos e variedades resistentes ou tolerantes. Todavia, freqüentemente 
observa-se plantas sintomáticas durante a avaliação de novos genótipos, visando o melhoramento genético e, ocasionalmente, em plantios comerciais. É importante lembrar que este vírus também incide sobre outras poáceas cultivadas, dentre as quais a cana-de-açúcar (Sacharum spp.) e o sorgo (Sorghum bicolor) $(11,12)$, o que pode aumentar a pressão de inóculo no campo.

A risca do milho, também conhecida por "rayado fino", em espanhol, ou "fine stripe" em inglês, caracteriza-se pela formação de pequenos pontos cloróticos nas folhas, os quais podem coalescer, adquirindo o aspecto de linhas pontilhadas e tracejadas, paralelas às nervuras foliares secundárias, assemelhando-se a riscas finas. O MRFV pertence ao gênero Marafivirus, família Tymoviridae (20). O vírus é transmitido de forma persistente-circulativa pela cigarrinha Dalbulus maidis, que também é vetora de dois outros importantes patógenos do milho, o Spiroplasma kunkelii, também conhecido como Corn stunt spiroplasma (CSS) e o Maize bushy stunt phytoplasma (MBSP), agentes causais do enfezamento-pálido e do enfezamento-vermelho, respectivamente (10). O período latente do vírus na cigarrinha varia com a temperatura ambiente, com relatos de 7 a 37 dias (10), após o qual será transmitido por quase todo o tempo de vida do inseto. $\mathrm{O}$ MRFV é encontrado do sul da América do Norte até toda a América do Sul, com relatos de perdas de até $43 \%$ em alguns países da América Central (18). No Brasil, a incidência isolada do MRFV não tem ocasionado grandes danos. No entanto, pelo fato de possuírem o mesmo inseto vetor, são comuns infecções mistas com os fitoplasmas e espiroplasmas, ocasionando danos de maior proporção na cultura do milho (10).

Este trabalho aborda o estudo detalhado dos agentes causais da elevada quebra na produção encontrada em um campo de milho, com plantas apresentando sintomas de mosaico, risca e redução no crescimento, relatando um tipo de interação pouco conhecida nessa cultura.

\section{MATERIAL E MÉTODOS}

\section{Coleta e indexação biológica das amostras}

Em uma lavoura de milho, no município de Santo Antonio da Posse, SP, cercada por lavouras de cana-de-açúcar, foram coletadas, durante o mês de março de 2005, plantas apresentando sintomas de mosaico, riscas (Figura 1A), nanismo e espigas com falhas no enchimento dos grãos (Figura 1B). O material foliar coletado foi inoculado mecanicamente em sorgo "Rio" e "TX 2786", e aveia (Avena sativa) "Astro". As inoculações foram realizadas com alíquotas de folhas das plantas infectadas, trituradas em nitrogênio líquido e diluídas na razão $1 / 10(\mathrm{p} / \mathrm{v})$ em tampão fosfato de sódio $0,01 \mathrm{M}, \mathrm{pH} 7,2$, com $0,1 \%$ de sulfito de sódio. O material foliar restante foi armazenado a $20^{\circ} \mathrm{C}$.

\section{Análise serológica}

O material foliar coletado foi submetido à análise por DAS-ELISA ("Double Antibody Sandwich - Enzyme Lynked Immunosorbent Assay"), com anti-soros da AGDIA (AGDIA Inc., Elkhart, Indiana, USA) para as espécies SCMV, JGMV, MDMV e MRFV, utilizandose controles positivos e negativos para cada espécie de vírus adquiridos da mesma empresa. Os procedimentos para as análises e os tampões utilizados seguiram as recomendações do fabricante. A atividade da enzima fosfatase alcalina conjugada aos anti-soros, correspondente à concentração dos vírus analisados, foi detectada pela adição de $1 \mathrm{mM}$ do substrato p-nitrophenyl phosphate em $10 \%$ de dietanolamina, $\mathrm{pH}$ 9,8 , com as leituras de absorbância realizadas a $405 \mathrm{~nm}$.

\section{Microscopia Eletrônica}

Amostras de folhas de milho apresentando os sintomas descritos foram analisadas por microscopia eletrônica de transmissão (TEM). Para observações em contrastação negativa do extrato foliar e também in situ empregou-se procedimento previamente descrito (2). Seções ultrafinas desse material foram obtidas num ultramicrótomo LKB III, contrastadas com acetato de uranila $2 \%$ e acetato de chumbo, e examinadas em TEM.

\section{Amplificação por RT-PCR}

O RNA total das folhas sintomáticas foi extraído com o reagente Trizol (Invitrogen, Carlsbad, Ca, USA). A transcrição reversa (RT) foi realizada empregando-se um oligo(dT) de 17 nucleotídeos, ancorado na extremidade 3' $\left(\mathrm{dT}_{17} \mathrm{~V}\right)$. Os primers senso SCMVF4 e SrMVF3 e os primers anti-senso SCMVR3 e SrMVF3 (21) foram usados para amplificar, especificamente, regiões do genoma correspondentes à capa protéica das espécies SCMV e SrMV. As reações de RT para obtenção do cDNA foram realizadas com o kit cMaster Rtplus (Eppendorf - Netheler, Hamburg, Germany) utilizando-se $2 \mathrm{mg}$ de RNA total, em combinação com $5 \mathrm{mM}$ do oligonucleotídeo $\mathrm{dT}_{17} \mathrm{~V}$, previamente incubados a $70^{\circ} \mathrm{C}$ por $10 \mathrm{~min}$. O cDNA proveniente da reação de RT foi amplificado com 2 combinações de primers: (i) $5 \mathrm{mM}$ do primer degenerado SCMVF4 e $1 \mathrm{mM}$ do primer SCMVF3; (ii) $1 \mathrm{mM}$ dos primers SrMVF3 e SrMVR3. As reações de PCR foram feitas com $2 \mathrm{~mL}$ do produto da RT por reação, seguindo as instruções do kit cMaster Rtplus. As amostras foram levadas para um termociclador MJ-Research PTC200 onde, após a desnaturação inicial a $94^{\circ} \mathrm{C}$ por $3 \mathrm{~min}$., a amplificação foi feita com 35 ciclos de $94^{\circ} \mathrm{C}$ por 1 min., $54^{\circ} \mathrm{C}$ por 2 min., $72^{\circ} \mathrm{C}$ por $3 \mathrm{~min}$., seguidos por uma extensão final a $72^{\circ} \mathrm{C}$ por $10 \mathrm{~min}$.

Os produtos de PCR foram analisados por eletroforese em gel de agarose $1,2 \%$, preparado em tampão TAE, $\mathrm{pH} 8,0$, corado com brometo de etídeo e observado sob luz UV. As seqüências de
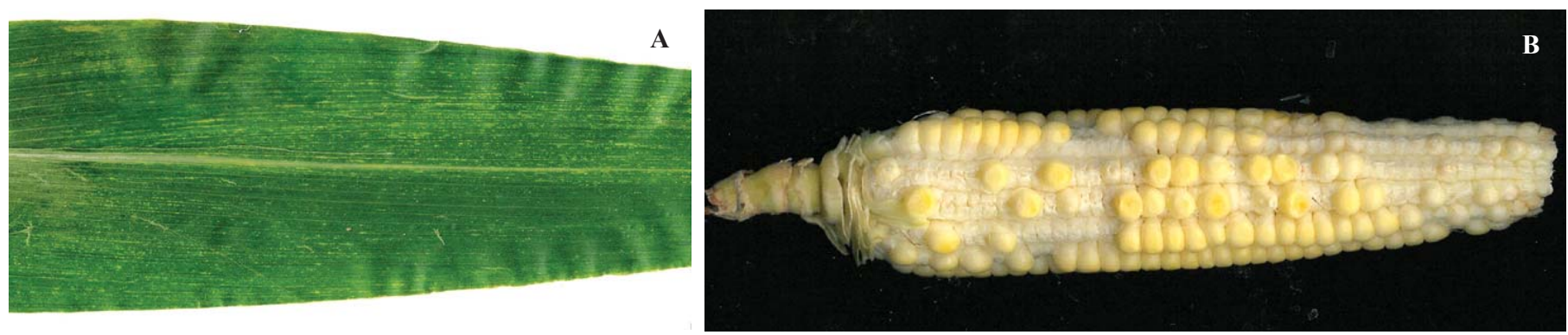

Figura 1. (A) Folha de milho apresentando sintomas de riscas e mosaico. (B) Espiga proveniente de planta infectada apresentando falha no enchimento dos grãos. 


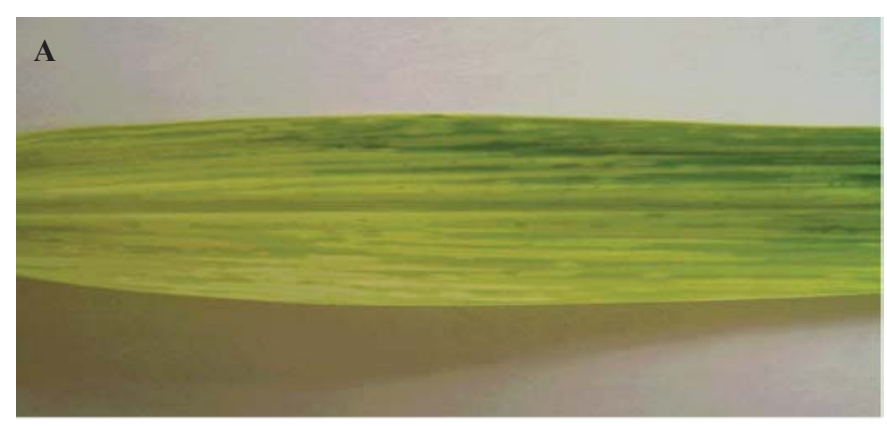

B

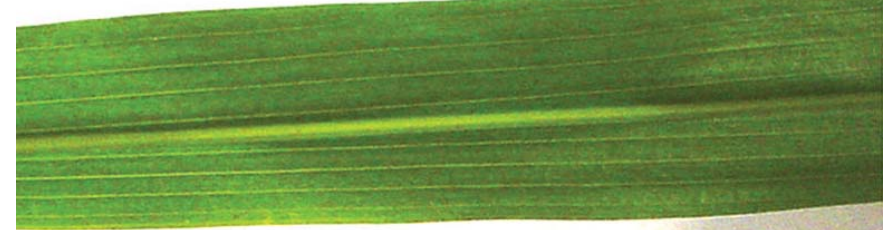

C

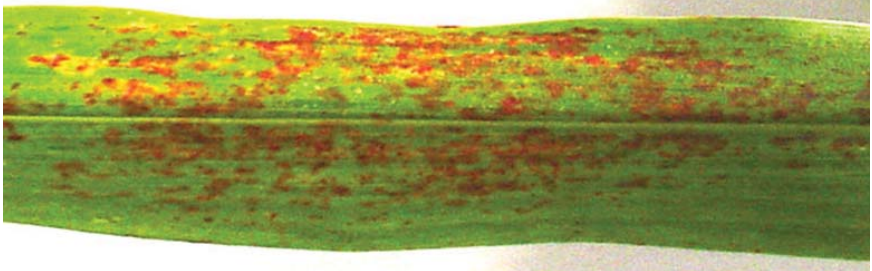

Figura 2. Folhas de plantas de sorgo "Rio" (Sorghum bicolor cv. Rio), inoculadas com o isolado de SCMV proveniente de milho. (A) inoculação no outono; (B) controle não inoculado; (C) inoculação no verão.

nucleotídeos e as deduzidas em aminoácidos resultantes foram analisadas e alinhadas com o software "Bio Edit - Sequence Alignment Editor" (5) e os consensos submetidos ao algoritmo BLAST disponível em www.ncbi.nlm.nih.gov, para comparação às seqüências depositadas no "GenBank". Alinhamentos múltiplos foram realizados com o software ClustalW e o grau de identidade de nucleotídeos foi determinado com o BioEdit.

Apesar dos sintomas do MRFV encontrados nas amostras, não foram realizados testes de RT-PCR para este vírus.

\section{Clonagem e seqüenciamento}

A purificação do DNA, a partir da banda selecionada e recortada do gel de agarose, foi feita com o kit Rapid Gel Extraction (GIBCO, BRL - Life Technologies, New York, USA). Os fragmentos de DNA foram clonados nos vetores pGEM-T Easy Vector System (Promega) e pCR2.1-Topo (Invitrogen) e transformados em Escherichia coli DH5 $\alpha$. Após a seleção dos clones recombinantes em meio contendo antibiótico, a presença dos fragmentos clonados nos respectivos vetores foi confirmada por digestão com a enzima de restrição EcoRI e posterior eletroforese em gel de agarose 1\%. Os fragmentos de DNA eluídos foram precipitados com etanol absoluto e acetato de sódio $3 \mathrm{M}$, pH 5,1. Os sedimentos obtidos foram ressuspensos em tampão TE, $\mathrm{pH}$ 8,0 e purificados em coluna Qiaquick (Qiagen). As seqüências de nucleotídeos do cDNA foram determinadas usando o kit "Big Dye" (Applied Biosystems Inc.), segundo protocolo do fabricante, e um seqüenciador automático modelo 3100 (Applied Biosystems Inc.). Três reações de seqüenciamento foram realizadas com cada oligonucleotídeo para a confirmação das seqüências obtidas.

\section{RESULTADOS E DISCUSSÃO}

As inoculações mecânicas provocaram mosaico típico, com diferentes intensidades, nas cultivares de sorgo Rio e TX 2786 (Figura 2A). Nos meses mais quentes do verão, algumas plantas de sorgo "Rio" inoculadas adquiriram, além do mosaico foliar, uma tonalidade avermelhada nas folhas e eventual necrose (Figura 2C). Por sua vez, as plantas de aveia inoculadas não apresentaram quaisquer sintomas, eliminando a possibilidade da infecção por um outro membro do subgrupo do SCMV, o JGMV. Esses resultados indicaram a infecção por uma estirpe do SCMV, devido aos sintomas de mosaico em sorgo. Porém, os sintomas de avermelhamento e necrose do tecido foliar em sorgo "Rio", levantaram a suspeita de tratar-se também da espécie SrMV, que costuma induzir sintomas semelhantes nessa planta indicadora $(1,15)$. Por sua vez, a infecção na cultivar de sorgo TX 2786, eliminou a possibilidade de tratar-se do SrMV, a qual não infecta essa cultivar (19) .

As amostras testadas por DAS-ELISA apresentaram-se positivas apenas para as espécies SCMV e MRFV. Por sua vez, as amostras de extratos foliares contrastadas negativamente e observadas em TEM, apresentaram partículas virais isométricas de ca. $30 \mathrm{~nm}$ de diâmetro, com alguns capsídeos com aspecto de vazios, nos quais houve a penetração do contrastante (Figura 3A). Essas partículas virais isométricas possuem tamanho e características da família Tymoviridae, a qual pertence o MRFV. Também foram
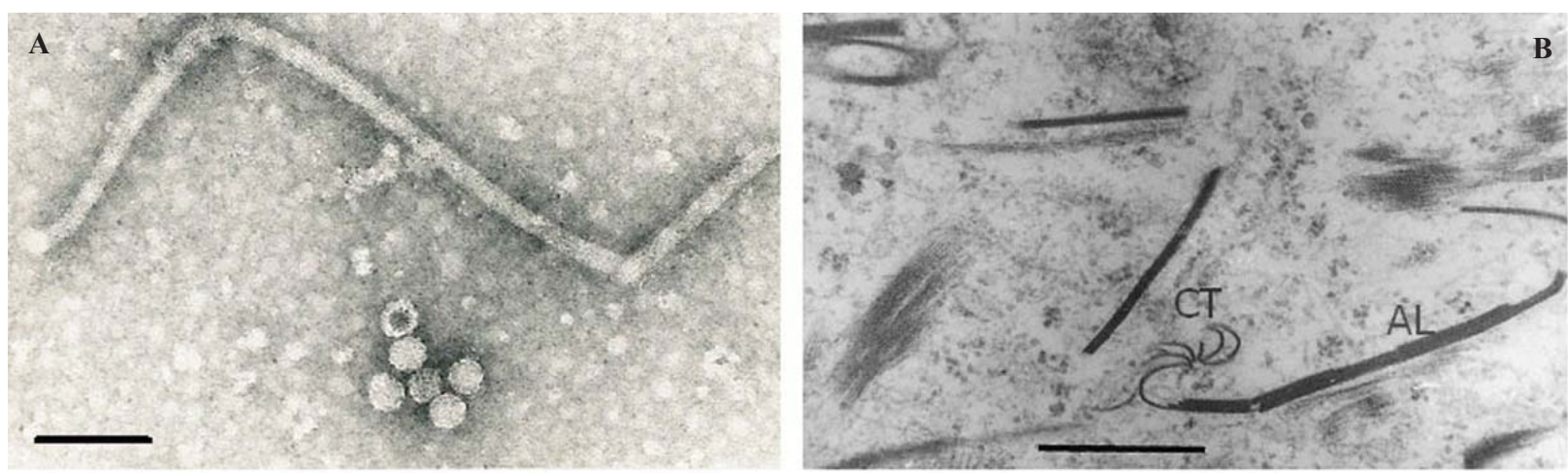

Figura 3 - (A) Micrografia eletrônica de transmissão de extrato foliar de milho com sintomas de mosaico e riscas mostrando partículas virais isométricas e partícula viral alongado-flexuosa, contrastadas negativamente com acetato de uranila $2 \%$. Barra de escala $=100 \mathrm{~nm}$. (B) Micrografia eletrônica de transmissão de corte ultrafino de folhas de milho com sintomas de mosaico e riscas, apresentando inclusões citoplasmáticas cilíndricas: cataventos $(\mathrm{CT})$ e agregados laminares $(\mathrm{AL})$. Barra de escala $=500 \mathrm{~nm}$. 


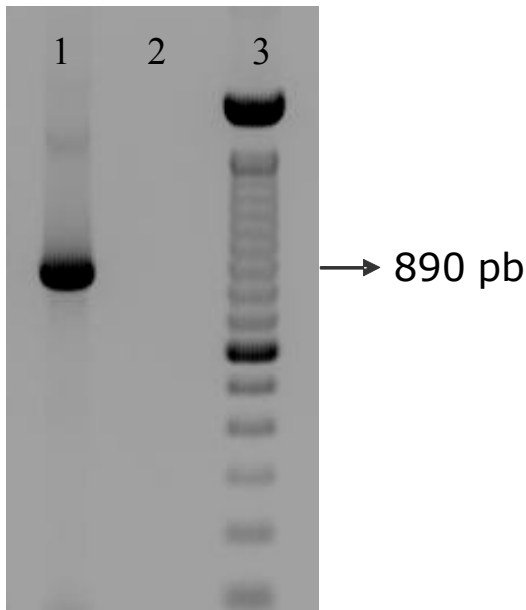

Figura 4 - Análise eletroforética dos produtos de RT-PCR com os oligonucleotídeos SCMVF4 e SCMVR3, a partir de RNA total extraído de folhas de milho e sorgo. Colunas 1: isolado SCMV de milho; 2: sorgo sadio; 3: marcador de tamanho de DNA (100 pb).

observadas partículas alongado-flexuosas com comprimento de ca. $770 \mathrm{~nm}$ (Figura 3A) e as seções ultrafinas apresentaram inclusões citoplasmáticas típicas de Potyviridae, dentre elas cataventos e agregados laminares (Figura 3B). Não foi observada a presença de espiroplasmas ou de fitoplasmas nas amostras analisadas. Esses resultados corroboram os obtidos na serologia, de infecção pelo MRFV e SCMV.

A análise eletroforética revelou a presença de bandas específicas de $890 \mathrm{pb}$, quando o par de primers SCMVF4 e SCMVR3 foi utilizado (Figura 4). A seqüência consenso de nucleotídeos obtida, correspondente à capa protéica do isolado de milho do SCMV (SCMVFER1), foi depositada no "GenBank" sob o número de acesso AY819719. A porcentagem de identidade das seqüências de nucleotídeos da capa protéica entre o isolado de milho do SCMV e outros isolados do vírus depositados no "GenBank" variou de 94 a $96 \%$, com maior identidade com isolados provenientes de cana-deaçúcar da Austrália e USA (Tabela 1). O alinhamento das seqüências de nucleotídeos desses isolados com o isolado de milho (dados não mostrados) mostra maior variabilidade na região $\mathrm{N}$-terminal da capa protéica, conforme esperado para o subgrupo do SCMV (14).

A incidência de mosaico na cultura do milho tem aumentado nos últimos anos devido, principalmente, ao grande aumento da área plantada no cultivo da "safrinha", fato que proporciona a sobreposição de ciclos da cultura e conseqüentemente a maior exposição aos afídeos vetores do SCMV. Apesar destes fatos, o mosaico não tem ocasionado grandes danos, com ocorrências esporádicas e isoladas. Comportamento semelhante tem ocorrido com a risca do milho, que apesar de bastante comum no Brasil, não tem assumido caráter epidêmico $(8,9)$. No entanto, são comuns infecções mistas do MRFV com o espiroplasma (CSS) ou o fitoplasma (MBSP), provavelmente pelo fato desses patógenos possuírem distribuição geográfica semelhante, compartilharem o mesmo vetor, a cigarrinha $D$. maidis, além de coabitarem os vasos floemáticos da planta de milho. Surtos epidêmicos desses tipos de infecções foram relatados ocasionando grandes danos na cultura do milho em anos recentes (10). Este trabalho, porém, apresenta a infecção mista do SCMV com o MRFV, provocando um quadro de sintomas mais severo do que em ocorrências isoladas desses patógenos e danos elevados à cultura, inviabilizando o seu cultivo comercial. Apesar dessas doenças não possuírem grande importância quando em ocorrência isolada, elas parecem adquirir um caráter sinérgico e provocar maiores danos quando incidem em infecções mistas na cultura do milho.

Este tipo de infecção pode ter ocorrido previamente em outras ocasiões, porém passada despercebida, provavelmente devido à falta da análise mais detalhada dos patógenos envolvidos. No entanto, a ocorrência de novas estirpes do subgrupo do SCMV tem ocasionado o relato freqüente de novos casos de mosaico, principalmente na cultura de cana-de-açúcar (4), que aliada ao cultivo do milho na "safrinha" tem proporcionado um aumento na pressão de inóculo no campo. Este é o caso da lavoura de milho abordada neste trabalho, cultivada em uma área com alta taxa de ocupação com cana-deaçúcar. A proximidade espacial entre as duas culturas também pode influenciar a taxa de distribuição do mosaico no campo, aumentando o número de focos de infecção e o número e a atividade do principal afídeo vetor ( $R$. maidis) que coloniza e transmite o SCMV para as duas espécies botânicas. No caso da cigarrinha $D$. maidis, vetora do MRFV, pouco se conhece sobre os seus hospedeiros alternativos, e são escassas as informações a respeito das estratégias de sobrevivência do inseto na ausência do milho (10). Entretanto, a relação do tipo persistentecirculativa permite que o MRFV permaneça no corpo do inseto e seja transmitido durante todo o seu período de vida, possibilitando a transmissão a partir de fontes de inóculo distantes, durante o período migratório. As características epidemiológicas dessas doenças, aliadas à peculiaridade do cultivo lado a lado das lavouras de milho e cana-de-açúcar, que tem aumentado principalmente no estado de São Paulo, pode ter proporcionado as condições para que essas viroses tenham ocorrido em infecções mistas, provocando maiores danos à cultura do milho.

\section{AGRADECIMENTOS}

Este trabalho foi financiado pela FAPESP mediante a concessão de um Projeto de Auxílio à Pesquisa a M.C.G (Processo 02/03697-8).

Tabela 1. Porcentagem máxima de identidade de nucleotídeos entre a seqüência da capa protéica do isolado de milho do Sugarcane mosaic virus (SCMV FER-1, AY819719) e as seqüências de outros isolados do vírus depositadas no "GenBank".

\begin{tabular}{|c|c|c|c|c|}
\hline Estirpe/isolado & Código de acesso no "GenBank" & País de Origem & Hospedeiro & Identidade $(\%)$ \\
\hline Isolado Isis-5 & AF006730 & Austrália & Sacharum spp & 96 \\
\hline Isolado Nambour 7 & AF006733 & Austrália & Sacharum spp & 96 \\
\hline Estirpe D & U57356 & USA & Sacharum spp & 95 \\
\hline Isolado Lou 44-1 & AJ491969 & USA & Sacharum spp & 95 \\
\hline Isolado Lou 45-1 & AJ491970 & USA & Sacharum spp & 95 \\
\hline
\end{tabular}




\section{REFERÊNCIAS BIBLIOGRÁFICAS}

1. Brunt, A.A.; Cratbree, K.; Dallwitz, M.J.; Gibbs, A.J.; Watson, L. Viruses of plants. Wallingford: CAB International, 1997.1484p.

2. Chagas, C., Colariccio, A., Galleti, S.R. \& Kitajima, E.W. Infecção natural de Amorphophallus konjac pelo vírus do mosaico do inhame no Brasil. Fitopatologia Brasileira, Brasília, v.18, n.4, p.551-554, 1993

3. Chaves, A.L.R.; Colariccio, A.; Eiras, M.; Fantin, G.M. Detecção e identificação serológica do Johnsongrass mosaic virus em milho no estado de São Paulo. Fitopatologia Brasileira, Brasília, v.26, supl., p.513, 2001. (Resumo).

4. Gonçalves, M.C.; Moreira, Y.J.C.B; Maia, I.G.; Santos, A.S.; Fantin, G.M.; Chaves, A.L.R.; Frangione, D.S.S.; Ulian, E.C. Identificação e caracterização de isolados pertencentes ao subgrupo do Sugarcane mosaic virus no estado de São Paulo. Fitopatologia Brasileira, Brasília, v.29, supl., p.129, 2004. (Resumo).

5. Hall, T.A. BioEdit: a user-friendly biological sequence alignment editor and analysis program for Windows 95/98/NT. Nucleic Acids Symposium Series, Oxford, v.41, p. 95-98, 1999.

6. Lesemann, D.E.; Shukla, D.D.; Tosic, M.; Huth, W. Differentiation of the four viruses of the sugarcane mosaic virus subgroup based on cytopathology. Archives of Virology, Viena, v.5, suppl., p.353-361, 1992.

7. MacKern, N.M.; Shukla, D.D.; Toler, R.W.; Jensen, S.G.; Tosic, M.; Ford, R.E.; Leon, O.; Ward, C.W. Confirmation that the sugarcane mosaic virus subgroup consists of four distinct potyviruses by using peptide profiles of coat proteins. Phytopathology, St. Paul, v.81, n.9, p.1025-1029, 1991.

8. Oliveira, E.; Carvalho, R.V.; Duarte, A.P.; Andrade, R.A.; Resende, R.O.; Oliveira, C.M.; Reco, P.C. Molicutes e vírus em milho na safrinha e na safra de verão. Revista Brasileira de Milho e Sorgo, Sete Lagoas, v.1, n.2, p.38-46, 2002.

9. Oliveira, E.; Oliveira, A.C. Incidência de enfezamento e de maize rayado fino virus em milho em diferentes épocas de plantio e relação entre a expressão de sintomas foliares dos enfezamentos e produção. Summa Phytopathologica, Jaboticabal, v.29, n.3, p. $221-224,2003$.

10. Oliveira, E.; Oliveira, C.M. Doenças em milho: molicutes, vírus, vetores, mancha por phaeosphaeria. Sete Lagoas: Embrapa Milho e Sorgo, 2004. 442p.
11. Pinto, N.F.J.A. Comportamento de cultivares de sorgo sacarino em relação ao vírus do mosaico da cana-de-açúcar. Fitopatologia Brasileira, Brasília, v.5, supl., p.438-439, 1980. (resumo).

12. Pinto, N.F.J.A. Vírus do mosaico comum da cana-de-açúcar em sorgo (Sorghum bicolor (L.) Moench): Caracterização de isolados, reação de cultivares e herança de resistência. 1984. Tese (Doutorado em Fitopatologia) Escola Superior de Agricultura Luiz de Queiroz, USP, Piracicaba.

13. Pirone, T.P. Sugarcane mosaic virus. Descriptions of Plant Viruses, Kew: CMI/AAB, n.88, 1972.

14. Shukla, D.D.; Frenkel, M.J.; McKern, N.M.; Ward, C.W.; Jilka, J.; Tosic, M.; Ford, R.E. Present status of the sugarcane mosaic subgroup of potyviruses. Archives of Virology. v.5, Suppl., p.363373,1992

15. Shukla, D.D.; Ward, C.W.; Brunt, A.A. The potyviridae. Cambridge: Cambridge University Press; CAB International, 1994. $516 \mathrm{p}$.

16. Seifers, D.L.; Salomon, R.; Marie-Jeanne, V.; Alliot, B.; Signoret, P.; Haber, S.; Loboda, A.; Ens, W.; She, Y.M.; Standing, K.G. Characterization of a novel potyvirus isolated from maize in Israel. Phytopathology, St. Paul, v.90, n.5, p.505-513, 2000.

17.Souza-Silva, C.R.; Ilharco, F.A. Afídeos do Brasil e suas Plantas Hospedeiras: Lista Preliminar. São Carlos, SP. EDUFSCar, 1995, 85p.

18. The CIMMYT Maize Program. Maize Diseases: A Guide for Field Identification. $4^{\text {th }}$ ed. Mexico, D.F.: CIMMYT, 2004. 119 p.

19. Tosic, M.; Ford, R.E.; Shukla, D.D.; Jilka, J. Differentiation of Sugaracane, Maize dwarf, Johnsongrass, and Sorghum mosaic viruses based on reactions of oat and some sorghum cultivars. Plant Disease, St. Paul, v.74, n.8, p.549-552, 1990.

20. Van Regenmortel, M.H.V.; Fauquet, C.M.; Bishop, D.H.L.; Carstens, E.B.; Estes, M.K.; Lemon, S.M.; Maniloff, J.; Mayo, M.A.; McGeoch, D.J.; Pringle, C.R.; Wickner, R.B. Virus Taxonomy Classification and Nomenclature of Viruses. Seventh Report of the International Committee on Taxonomy of Viruses. Califórnia: Academic Press, 2000.1162p.

21. Yang, Z.N.; Mirkov, T.E. Sequence and relationships of sugarcane mosaic and sorghum mosaic virus strains and development of RT-PCR-based-RFLPs for strain discrimination. Phytopathology, St. Paul, v.87, n.9, p.932-939, 1997. 